\title{
The Impact of Social Media on Communication Politeness: A Survey of Prospective Primary School Teacher Students
}

\author{
J.Julia ${ }^{\varpi 1}$, Dadang Kurnia², and Ali Sudin ${ }^{3}$ \\ 1,2,3 Prodi PGSD Sumedang, Universitas Pendidikan Indonesia, Bandung, Indonesia \\ $\bowtie$ juli@upi.edu
}

\begin{abstract}
The presence of social media in our daily life gives both its positive and negative impact to communication manners. This impact also occurs in schools' environment or even in campus. This paper aims to analyze students' politeness in communicating through the social media. The study was conducted by providing a survey to 147 students (ages between 19-24 years). The results of the study prove that communication through social media give an impact on students to be more eager to communicate with anyone. However, their communication politeness has decreased, as the survey shows that the ethics of communicating through social media are nor good or polite. Therefore, it can be concluded that the social media has influenced the communication politeness between students and students and between students and lecturers.
\end{abstract}

Keywords: Communication politeness, social media, technology literacy.

How to Cite: Julia, J., Kurnia, D., \& Sudin, A. (2018). The Impact of Social Media on Communication Politeness: A Survey of Prospective Primary School Teacher Students. Mimbar Sekolah Dasar, 5(3), 125-130. doi:http://dx.doi.org/10.17509/mimbar-sd.v5i3.14492.

INTRODUCTION Technology helps human

life to learn, move, work, communicate, and develop in general. In other words, there may only be a slight hesitation that technology-both in its development and value proportion-when it combined with human growth, it will make a significant influence to monetary development, in which prove to be fundamental element in human growth developments as a civilization's bottom-line accomplishment (Haenssgen and Ariana, 2018; Ranis and Zhao, 2013; Sahay and Walsham, 2017).

In utilizing various facilities provided by technology, intelligence and wisdom are needed because without them, technology can be a disaster for human life
(Angelini \& Gibson, 2007; Fagin, 1991; Wall, 1995).

Current phenomenon indicates that there is a decrease in communication politeness among students. This was allegedly due to the presence and the use of communication media in form of social media. Therefore, this paper tries to examine and analyze how ethical reality of students in communicating both with peers and with lecturers.

Various research results shown significant results on this problem. For example, Bunz and Campbell (2004) provide a basis for explaining matters of connection making, communication accommodation in an electronic setting, and discourse study in 
J. Julia, Dadang Kurnia, and Ali Sudin, The Impact of Social Media on Communication Politeness...

online communication. Meanwhile, Rimkuniene and Zinkeviciute (2014), designate that social media has a big latent for enhancing collective initiatives and accumulating suggestion for the tactical forecasting. Morreale, Staley, Stavrositu, and Krakowiak (2015) afford a representation of Generation C students' (born after 1990) imageries of how they really desire to communicate, in formal and more private condition and association. The students showed an inclination to personally communicate in all of 10 communication conditions, with some alterations based on students' gender. Different from the previous studies, in this study, we try to deepen the study of ethical issues (politeness) used by students in communication dimension, including finding the differences in the ways of communicating between a direct communication without social media and communication through social media. Communication ethics in the context of the campus environment or social environment, especially in Indonesia, are quite diverse. For example, it could include the use of language levels (based on age and social relationships), the use of greetings, the timing of communication, the use of the word "sorry," and the use of "thanks." This research was conducted in Sundanese culture setting, the second largest ethnicity in Indonesia.

\section{METHODS}

This study used a survey method with a qualitative approach. The number of subjects surveyed consisted of 147 students from four classes in one batch. They consist of 117 women and 30 men. Their age ranges from 19-24 years. Their area of origin is quite a diverse spread from the province of West Java, as many as 49 people (33.3\%) are from Sumedang, 28 people (19\%) are from Cirebon, 24 people (16.3\%) are from Bandung, and 46 people (31.4\%) are from other areas in and outside of West Java. Students are assigned to fill out surveys to uncover their ethics in communicating through social media, both communications between students and between students and lecturers. The survey was conducted through Google Docs using a Likert and Gutman scales, and open-ended questions. Google Docs is an easy-to-use, a freely-available surveycreation tool with a variety of question types that should meet the needs of most survey creators (Travis, 2010).

\section{RESULTS AND DISCUSSION}

The results of the study were categorized into two topics, i.e. students' technology literacy, and social media relations with student communication ethics. Through these two topics, we analyze how social media impacts students' communication ethics.

\section{Technology Literacy}

We explore the extent to which students know and use technology. The survey results can be seen in Table 1 below. 
Table 1. Technology literacy

\begin{tabular}{lcc}
\hline Technology literacy & Yes & No \\
\hline Are you tech literate? & 132 & 15 \\
Do you always follow technologydevelopment (innovation)? & 131 & 16 \\
Do you have high-tech devices (such as computers / laptops / gadgets / & 143 & 4 \\
smart phones / tablets)? & & \\
\hline
\end{tabular}

Based on Table 1, it can be identified that the majority of students (89.8\%) claimed to have high-tech devices. This was confirmed by their acknowledgment (89.1\%) which stated that they were always up to date with technological developments, and their recognition (97.3\%) stated that they possessed high-tech devices. Thus, it can be seen that the majority of students are the users of high-tech devices. One student / respondent (R) gave a reason, 'because technology can help it users to simplify the time and meet the needs, especially in communicating properly, faster, easier and broad coverage' (R1). For example, mobile phones and phone-based services could be seen as logical solutions to improve service access (Haenssgen\&Ariana, 2018).

Through open questions, students were asked, "What technology do you often use?" Student answers showed that 100 students (68\%) used gadget technology, 46 students (31.3\%) used Internet technology, and one student $(0.7 \%)$ used computer technology. Here, it can be seen that the majority of students are gadget users. They provide various reasons related to the use of the gadget. One student gave a reason 'because gadgets can handle the work that is usually done on a computer / laptop and can be connected to the Internet, its smaller size than a computer also makes it easy and quite helpful in doing something' (R2). There are also students who give a reason 'because gadget is more efficient and easier to be brought everywhere, and it felt useful in supporting my needs as a student in finding and digging up information, and I can also use it as a means of existence and interaction with friends' (R3). Moreover, a student gives reasons' because it is easy to be brought and has minimalist in size, so if it does not bring it like losing something, and gadgets today are becoming very important things, because there are so many applications that are associated with daily needs i.e. online shopping and Google Maps, and gadgets are very sophisticated today' (R4). Some of the arguments given by the students shown how gadgets are essential to life. Likewise, the function of a gadget that can replace or represent the Internet and computer facilities, even today's mobile phone is a universal tool. It has become such an important aspect of a user's daily life that it has moved from being a merely 'technological object' to a key 'social object' (Srivastava, 2005). 
J. Julia, Dadang Kurnia, and Ali Sudin, The Impact of Social Media on Communication Politeness...

They were asked, "Where do you learn technology a lot?" A total of 103 students (70.1\%) was searched by themselves in the Internet. As many as 32 students (21.8\%) searched it from their friends, and 12 students (8.2\%) obtained it from lectures. Thus, the majority of students learned the technology through the Internet. One student gave a reason: "in my opinion, Internet is the main source that can access all things in various fields, both in terms of education, health, social and all things that cannot be physically accessed can be accessed through the Internet' (R5). As stated by Huang, Hsueh, and Lin (2002), that www is the most common way for heterogeneous, distributed information representation and sharing on the Internet.

\section{Social Media and Communication Ethics}

After we identified that student majority were users of high-tech communication devices, we explored several things related to the influence of using communication devices in form of social media on communication ethics.

Table 2. Impact of technology on communication

\begin{tabular}{lll}
\hline Impact of technology on communication & Yes & No \\
\hline $\begin{array}{l}\text { Do you think that technological development affect the ways and ethics } \\
\text { of communication? }\end{array}$ & 146 & 1 \\
$\begin{array}{l}\text { Does the presence of technology make you more courageous to } \\
\text { communicate with anyone? }\end{array}$ & 119 & 28 \\
\hline
\end{tabular}

Table 2 shows that almost all students (99.3\%) agreed that ethic in communication is influenced by technological developments. In fact, in majority of $(81 \%)$ admit that they are more courageous to communicate with anyone

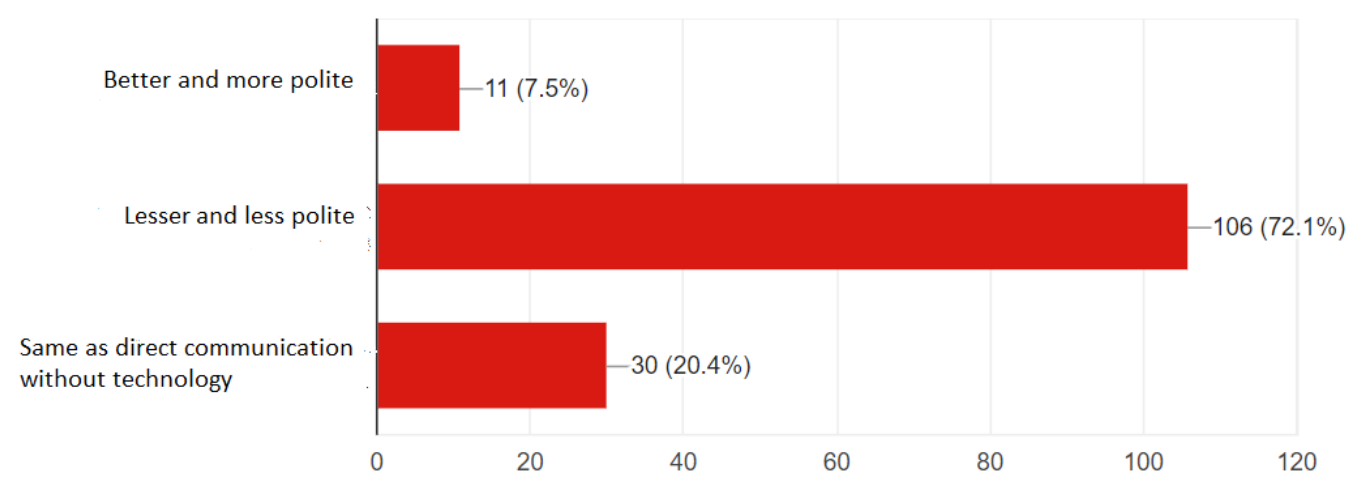

Figure 1. Student perspective on the effect of technology on communication because of the technology. We explore further, by asking them, "Where are the effects of technology (such as social media) on communicating ethics?" The results can be seen in Figure 1 below. 
Based on Figure 1, it can be identified that total of 106 students $(72.1 \%$ ) stated that communication was not good and less polite, 30 students $(20.4 \%)$ stated that communication was equal with direct communication without technology, and as 11 students (7.5\%) stated that communication is better and polite. In other words, technology can provide great benefits for humans, but can also bring harm (Boddy \& Dominelli, 2017). This is evident in the statement of students, who admitted that as many as $40.1 \%$ had problems due to poor communication through social media. The reason is quite diverse, as experienced by one student, 'because of a less polite language, there is a misunderstanding' (R6).

We also explore how (ethics) they communicate, both with peers and with lecturers. The research was conducted through a Likert scale with the choice of Very Impolite (VI), Impolite (I), Slightly Polite $(\mathrm{SP})$, Polite (P), and Very Polite (VP). Their response can be seen in table 3 below.

Table 3. How students communicate

\begin{tabular}{llllll}
\hline How students communicate & $\mathrm{VI}$ & $\mathrm{I}$ & $\mathrm{SP}$ & $\mathrm{P}$ & $\mathrm{VP}$ \\
\hline $\begin{array}{l}\text { How do you communicate with peers without using } \\
\text { social media? }\end{array}$ & 2 & 0 & 53 & 76 & 16 \\
$\begin{array}{l}\text { How do you communicate with peers through social } \\
\text { media? }\end{array}$ & 3 & 1 & 67 & 64 & 12 \\
$\begin{array}{l}\text { How do you communicate with lecturers without using } \\
\text { social media? }\end{array}$ & 2 & 2 & 12 & 38 & 93 \\
$\begin{array}{l}\text { How do you communicate with lecturers through } \\
\text { social media? }\end{array}$ & 2 & 0 & 13 & 43 & 89 \\
\end{tabular}

Through Table 3, it can be identified that the majority $(51.7 \%)$ communicate politely with their peers without the social media. However, this fact changed when they communicate through social media. The majority of (45.6\%) communicated less polite. Meanwhile, if they communicate with the lecturers, students in majority (63.3\%) claimed to communicate very well without the social media. However, politeness decrease (60.5\%) when they communicate through the social media. From both directions of communication showed a decrease in politeness when they communicate through the social media. Therefore, the results of Bowen (2013) research remind us that to maintain our best, most ethical selves; social media should be used to encourage the good, to laud the praiseworthy, and to encourage that which we most value about ourselves and in our organizations.

\section{CONCLUSION}

Based on the results of the study, it can be concluded that the students in majority are technology literate. They are gadget users and social media users. They also agreed 
J. Julia, Dadang Kurnia, and Ali Sudin, The Impact of Social Media on Communication Politeness...

that technology had a negative impact on communication ethics. As a result, the use of social media makes student politeness in communicating with both peers and lecturers decreased.

\section{REFERENCES}

Angelini, D., \& Gibson, S. (2007). Organized Crime and Technology. Journal of Security Education, 2(4), 65-73. doi:10.1300/J460v02n04_07

Boddy, J., \& Dominelli, L. (2017). Social Media and Social Work: The Challenges of a New Ethical Space. Australian Social Work, $70(2), 172-184$. doi:10.1080/0312407X.2016.1224907

Bowen, S. A. (2013). Using Classic Social Media Cases to Distill Ethical Guidelines for Digital Engagement. Journal of Mass Media Ethics, 28(2), 119-133. doi:10.1080/08900523.2013.793523

Bunz, U., \& Campbell, S. W. (2004). Politeness Accommodation in Electronic Mail. Communication Research Reports, 21(1), 11-25. doi:10.1080/08824090409359963

Fagin, J. A. (1991). Computer Crime: A Technology Gap. International Journal of Comparative and Applied Criminal Justice, 15(1-2), 285-297. doi:10.1080/01924036.1991.9688974

Haenssgen, M. J., \& Ariana, P. (2018). The place of technology in the Capability Approach. Oxford Development Studies, $\quad 46(1)$, 98-112. doi:10.1080/13600818.2017.1325456

Huang, S.-M., Hsueh, H.-Y., \& Lin, B. (2002). Information Sourcing from the Internet and its Verification. Journal of Computer Information Systems, 42 (3), 94-105.

doi:10.1080/08874417.2002.11647508

Morreale, S., Staley, C., Stavrositu, C., \& Krakowiak, M. (2015). First-Year College Students' Attitudes toward Communication Technologies and Their Perceptions of Communication
Competence in the 21st Century. Communication Education, 64(1), 107131. doi:10.1080/03634523.2014.978799

Ranis, G., \& Zhao, X. (2013). Technology and Human Development. Journal of Human Development and Capabilities, $\quad$ 14(4), 467-482. doi:10.1080/19452829.2013.805318

Rimkuniene, D., \& Zinkeviciute, V. (2014). Social media in communication of temporary organisations: role, needs, strategic perspective. Journal of Business Economics and Management, 15(5), 899-914. doi:10.3846/16111699.2014.938360

Sahay, S., \& Walsham, G. (2017). Information Technology, Innovation and Human Development: Hospital Information Systems in an Indian State. Journal of Human Development and Capabilities, 18(2), 275-292. doi:10.1080/19452829.2016.1270913

Srivastava, L. (2005). Mobile phones and the evolution of social behaviour. Behaviour \& Information Technology, $24(2)$, 111-129. doi:10.1080/01449290512331321910

Travis, L. (2010). One of Many Free Survey Tools: Google Docs. Journal of Electronic Resources in Medical Libraries, $\quad 7(2)$, 105-114. doi:10.1080/15424065.2010.482902

Wall, D. S. (1995). Technology and crime: Increased capital investment in information technology and changes in victimization patterns. International Review of Law, Computers \& Technology, 9(1), 97-109. doi:10.1080/13600869.1995.9966414 